\title{
ПАРА-ЗАМЕЩЁННЫЕ 2,6-ДИ-ТРЕТ-БУТИЛФЕНОЛЫ С ПИРИДИНОВЫМ ФРАГМЕНТОМ КАК ПЕРСПЕКТИВНЫЕ РАДИОПРОТЕКТОРЫ
}

\author{
Е.А. Никитин ${ }^{1}$, Е.Р. Милаева ${ }^{1,2}$ \\ ${ }^{1}$ Химический факультет, Московский государственный университет \\ им. М.В. Ломоносова, 119991, Россия, Москва, Ленинские горы, 1, с. 3. \\ ${ }^{2}$ Институт физиологически активных веществ РАН, \\ 142432, Россия, Черноголовка, Северный проезд., 1.
}

DOI: 10.19163/MedChemRussia2021-2021-126

E-mail: evgeny.a.nikitin@yandex.ru

Лучевая терапия является одним из основных методов лечения онкологических заболеваний, однако сопутствующие поражения здоровых тканей могут являться причиной патологий в организме. В этой связи, разработка новых радиозащитных препаратов является важной задачей.

Антиоксиданты являются ингибиторами цепных радикальных процессов, разрушающих биологический субстрат, и могут выступать в роли радиопротекторов. Пространственно-затруднённые фенолы являются миметиками витамина Е и обладают цитопротекторными свойствами. Целью данной работы является исследование радиозащитных свойств соединений 1-6 и 1А-6А, содержащих фрагмент 2,6-ди-трет-бутилфенола и обладающих доказанной антиоксидантной активностью [1].

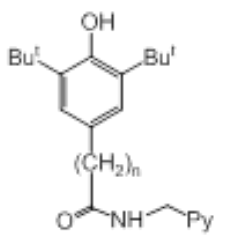

$1-6$

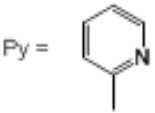

$n=0 \quad(1,1 A)$

$n=2 \quad(4,4 A)$

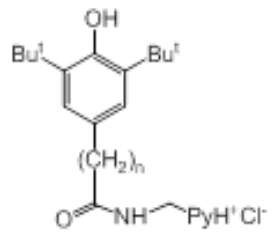

1A-6A

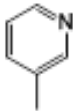

(2, 2A)

$(5,5 \mathrm{~A})$

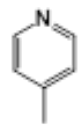

$(3,3 \mathrm{~A})$

$(6,6 \mathrm{~A})$

Активность соединений в роли радиопротекторов исследована в тестах с плазмидной ДНК и радикальным гидроксилированием кумарина. Показано, что соединения 1-6 и 1А-6А обладают заметными радиозащитными свойствами и способны нейтрализовывать радиосенсибилизирующий эффект наночастиц золота. Полученные результаты позволяют предложить синтезированные соединения в качестве перспективных радиопротекторов.

Работа выполнена при финансовой поддержке РФФИ (№ 19-33-90236).

\section{Литература}

[1] E. Nikitin, D. Shpakovsky, A. Pryakhin, T. Antonenko, V. Tyurin, A. Kazak, A. Ulyanov, V. Tafeenko, L. Aslanov, L. Dubova, E. Lysova, E. Shevtsova, E. Milaeva, Pharmacy \& Pharmacology International Journal. 2020, 8, 122-134. 